Original Research Article

\title{
Synergistic antimicrobial activity of crude ethanolic extracts of garlic and neem leaves against bovine mastitis pathogens: an in vitro assay
}

\author{
Makhulu Edmond Edward ${ }^{1 *}$, Nyaga Nderitu Samuel², Wambugu Stanely², Areba Gerald ${ }^{2}$
}

\author{
${ }^{1}$ Department of Biochemistry \\ and Molecular Biology, \\ ${ }^{2}$ Department of Veterinary \\ Anatomy and Physiology, \\ Egerton University, Nakuru, \\ Kenya \\ Received: 06 July 2017 \\ Revised: 12 July 2017 \\ Accepted: 29 July 2017 \\ *Correspondence to: \\ Makhulu Edmond Edward, \\ Email: edwardmakhulu@ \\ gmail.com \\ Copyright: (C) the author(s), \\ publisher and licensee Medip \\ Academy. This is an open- \\ access article distributed under \\ the terms of the Creative \\ Commons Attribution Non- \\ Commercial License, which \\ permits unrestricted non- \\ commercial use, distribution, \\ and reproduction in any \\ medium, provided the original \\ work is properly cited.
}

\begin{abstract}
Background: Treatment of bovine mastitis (BM) is highly expensive necessitating better and affordable control strategies. Synergy of plant extracts against microbes associated with BM stand unexploited. Therefore, this study sought to evaluate the sensitivity of major bovine mastitis bacteriaStaphylococcus aureus and Escherichia coli to combination of two traditional herbal plants, garlic and neem, widely used in East Africa.

Methods: Maceration and soxhlet processes were used to obtain crude ethanolic extracts of neem extracts (NE) and garlic (GE) respectively. The extracts were used to determine Minimum Inhibition Concentration (MIC) against test pathogens. Synergy was investigated by combining the two extracts at different concentrations and determining colony forming units per liquid medium $(\mathrm{CFU} / \mathrm{ml})$ using turbidity as a measure of inoculum growth.

Results: NE was effective against S. aureus at $200 \mu \mathrm{g} / \mathrm{ml}$ and $100 \mu \mathrm{g} / \mathrm{ml}$ (average zone of inhibitions were $11 \pm 0.5774 \mathrm{~mm}$ and $10 \pm 0.5774 \mathrm{~mm}$ respectively). E. coli was resistant to NE. GE was effective against S. aureus at $200 \mu \mathrm{l} / \mathrm{ml}$ and $100 \mu \mathrm{l} / \mathrm{ml}$ (average zones of inhibition were $14 \pm 0.8819 \mathrm{~mm}$ and $12 \pm 0.8819 \mathrm{~mm}$ respectively). GE was effective against $E$. coli only at $200 \mu 1 / \mathrm{ml}$ with an average zone of inhibition of $11 \pm 0.5774 \mathrm{~mm}$.

Conclusions: There was synergy when garlic MIC was combined with NE MIC. Increase in concentration of GE above its MIC increased the rate of decrease of the CFU. No significant change was shown when NE concentration was increased above its MIC. The combination of NE and GE can have additive effect in treatment $\mathrm{S}$. aureus mastitis while GE can supplement NE resistance.
\end{abstract}

Keywords: Colony forming units, Escherichia coli, Minimum inhibition concentration, Staphylococcus aureus, Turbidity

\section{INTRODUCTION}

Kenya dairy sector is one of the best in Africa due to the approximately 5.2 billion liters of milk produced annually which has been able to contribute almost $4 \%$ to the country's GDP either direct or indirectly. ${ }^{1,2}$

However this sector is under threat owing to varies economic losses associated directly with mastitis like reduction in milk production, treatment and control cost, milk discarding due to mastitis and drug residues, replacement of prematurely culled cows and rise of risk of other infectious diseases.

\begin{abstract}
Mastitis, an udder disease associated with inflammation of the mammary glands, is the most prevalent of bovine diseases in Kenya. Despite the fact that it has a variety of causative agents, in Kenya E. coli and Staphylococcus aureus have the highest prevalence contributing $20.6 \%$ and $20.1 \%$ respectively of the reported cases. ${ }^{3}$ Based on the fact that the bulk of the causative agents are bacteria, antibiotic therapy is the most used method in control of mastitis. However it is expensive and in addition overuse and misuse of antibiotics in the veterinary sector has resulted to resistant strains to treatment. ${ }^{4}$ Development of such new antibiotics faces significant challenges like high cost of pharmaceutical research and development, which
\end{abstract}


makes antimicrobial agents less economically attractive targets for pharmaceutical companies. ${ }^{5}$ Despite the success of alternatives like resistance modifying agents, phage therapy, bacteriocins, chelation, vaccination, biotherapy, host defense peptides and antibacterial coating, they have proven to be unreliable and much more expensive. ${ }^{6}$ An example is the development of a mastitis vaccine where lots of vaccines have been developed but few had satisfactory results, necessitating cheap and efficient steps in controlling this disease. ${ }^{7}$

Phytotherapy offers a cheap and equally beneficial alternative in tackling antibiotic resistant in treating bovine mastitis. ${ }^{8}$ Natural products are a rich and promising source for the discovery of new biologically active compounds. ${ }^{9}$ Plants like Azadirachta indica (neem) have been used extensively in the veterinary field in treatment of a number of diseases, udder infections being one of them. ${ }^{10}$ Neem has been shown to have significant potency against $S$. aureus. ${ }^{11}$ Another common traditional medicinal plant is Allium sativum (garlic) which contains an active component called allicin which has significant antimicrobial activity. ${ }^{12}$

However, bioactive molecules in plants vary in potency hence efficacy of the extracts obtained also vary in their antibacterial activity. Similarly chances of lack of antibacterial activity by the plant extracts is possible. An example is the reported resistance of $E$. coli against ethanolic extracts from neem leaves. ${ }^{12}$ Therefore, synergistic studies of plant extracts to identify a novel combination with much desired efficacy are needed. ${ }^{8}$ In this study, the focus was to investigate the influence of synergy of crude ethanolic extracts of garlic (Allium sativum) and Neem (Azadirachta indica) on E. coli and $S$. aureus major causative agents of bovine mastitis in Kenya.

\section{METHODS}

\section{Plant collection}

Mature brown garlic bulbs were obtained from the Nakuru Municipal Council Market in Nakuru town while Neem leaves was collected from Kisauni in Mombasa County and positively identified by a botanist at the Department of Biological Science of Egerton University and voucher specimens deposited in their herbarium. Both plant materials were collected during the month of January. The garlic bulbs were washed with distilled water and subjected to surface sterilization with $70 \%$ ethanol. Neem leaves were cleaned and shade dried for one week and completely crushed to powder.

\section{Preparation of extracts}

\section{Neem sap extraction from leaves}

Crude extraction of Neem leaves was done according to with minor modification. Neem powder $(100 \mathrm{~g})$ was mixed in $500 \mathrm{ml}$ of $70 \%$ ethanol and occasional shaken for a week. ${ }^{13}$ The flask was kept in the dark condition to avoid effects of light on the active ingredients of Neem. Filtration of the mixtures was done using Whatman No.1 filter paper and the filtrate evaporated to dryness by placing them in the oven at constant temperature of $60^{\circ} \mathrm{C}$ for four days. The obtained residues were stored at $4^{\circ} \mathrm{C}$ for further use. Four different concentrations, 25, 50,100 and $200(\mathrm{mg} / \mathrm{ml})$ in $20 \%$ dimethyl sulfoxide (DMSO) were prepared for use.

\section{Garlic extraction from bulbs}

Garlic extraction was performed according to with some slight modification via soxhlet extraction method using ethanol (boiling point $40-60^{\circ} \mathrm{C}$ ) for a period of six hours. ${ }^{14}$ The extract was obtained after the solvent was reduced under pressure and temperature and refluxed at $70^{\circ} \mathrm{C}$ to remove excess solvent. The extract was refrigerated at $2{ }^{\circ} \mathrm{C}$ for later use. Four different concentrations 25, 50,100 and $200(\mathrm{mg} / \mathrm{ml})$ in $20 \%$ dimethyl sulfoxide (DMSO) were prepared.

\section{Sterility test}

A sterility test was carried out to ensure that the extracts were completely sterile. This test involved the crude plant extracts being cultured on Nutrient agar (HiMedia, Mumbai, India) overnight at $37^{\circ} \mathrm{C}$. A nutrient agar plate incubated with $E$. coli was used as positive control for bacterial growth while a freshly prepared nutrient agar plate was used as a negative control to bacterial growth.

\section{Sensitivity disc preparation}

Sensitivity discs ( $5 \mathrm{~mm}$ diameter) discs were prepared from Whattman No.1 filter paper. The discs were sterilized by autoclaving them at $12^{\circ} \mathrm{C}$ and hot dried at $50^{\circ} \mathrm{C}$ in an oven. This was followed by preparation of the various solvent extract discs by soaking them in the extracts of known concentration for 15 minutes to impregnate them with the extracts.

\section{Evaluation of antibacterial activity and determination of MIC}

Evaluation of antibacterial activity was conducted in vitro using Paper-Disc Diffusion method. S. aureus and E. coli obtained from the Department of Veterinary Clinical studies, Egerton University, bacterial stock and plated on nutrient agar to obtain distinct colonies. The bacterial colonies obtained were diluted with Normal Saline (approximately $\mathrm{pH} 5.5$ ) and thoroughly shaken while comparing with $0.5 \mathrm{McF}$ arland standard prepared to obtain approximately $1.5 \times 10^{5} \mathrm{CFU} / \mathrm{ml}$ and was used in the sensitivity test. The sensitivity test was carried out on Muller- Hinton agar (HiMedia, Mumbai, India) using the sensitivity discs prepared. The negative control used was DMSO while the positive control was Gentamicin. The zones of inhibition were measured and the MIC 
determined as the lowest concentration that completely inhibited growth of the organisms being test.

\section{Synergism test}

After determination of the MIC for each extract, synergistic effects on the test organisms was determined by checking the rate of growth inhibition of the test samples at varying time. The percentage viability of the test organisms was check at a period of $0,4,8,12$ and 24 hours. First the growth inhibition assay of the MIC of the plant extracts were done individually then the percentage viability for various combinations between the extracts MIC with the concentrations above the MICs were done. To $1 \mathrm{ml}$ of the microbial broth, $1 \mathrm{ml}$ of each of the crude extract was added making a final volume of $3 \mathrm{ml}$ of our sample $(1 \mathrm{ml}$ of microbial broth $+1 \mathrm{ml}$ of a given GE concentration $+1 \mathrm{ml}$ of a given $\mathrm{NE}$ concentration). The absorbance was conducted at a wavelength of $696 \mathrm{~nm}$ which is the approximate wavelength at which $S$. aureus absorbs light. 20\% DMSO and gentamicin at a concentration of $200 \mu \mathrm{l} / \mathrm{ml}$ were used as the negative and positive controls respectively.

\section{Statistical analysis}

Efficacy of the extracts against the antibacterial isolates was determined through measurement of the diameter of inhibition. Data was expressed in mean \pm standard deviation and $\mathrm{T}$ test was conducted to compare results between the positive control and results obtained from the plant extracts. $\mathrm{P}$ values less than $0.05(\mathrm{P}<0.05)$ were considered statistically significant. Microsoft Excel 2013 data analysis tool was used for the statistical analysis.

\section{RESULTS}

\section{Crude extraction and purity of the crude extracts}

A black colored sticky solid was obtained from dried neem leaves as shown in Figure 1A. Garlic ethanolic extract was a yellow liquid with a pungent smell (Figure 1B). After concentration of the garlic extract in rotary evaporator, a slightly viscous liquid was formed. The extracts were found to have no contamination from microbes after conducting the sterility test.

In accordance to a previous study, dried neem leaves were selected as the best during extraction. ${ }^{13}$ This is because they are easy to crush and also they improve stability of the secondary metabolites, which are to be used as antimicrobial agents, due to enzyme inhibition. ${ }^{10}$ Ethanol was selected as the solvent of choice unlike in the previous study by where methanol was used. ${ }^{13}$ This was mainly due to ethanol having a polarity which was almost closer to that of methanol despite ethanol being the most abundant solvent in the laboratory. Ethanol has a polarity of 5.2 and that of methanol is 5.1.15 Furthermore ethanol was also selected based on the results of which showed that ethanolic Neem extract showed much higher antibacterial activity. ${ }^{16}$

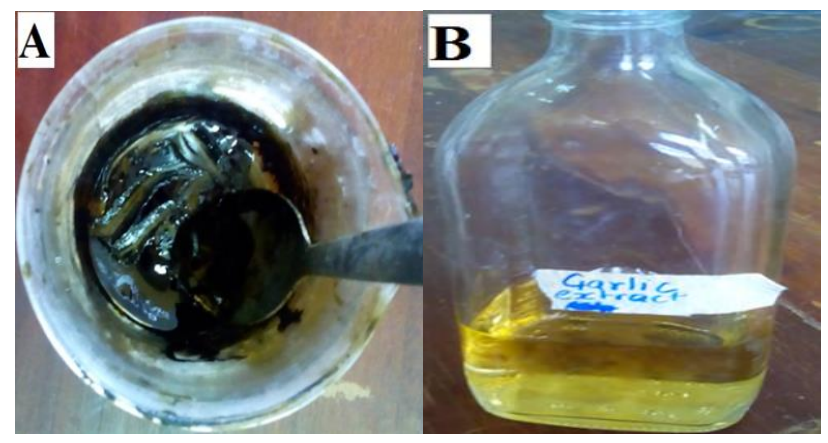

\section{A.) Neem leave extracts B.) Garlic extract}

Figure 1: Final extracts from Neem $(A$. indica $)$ leaves and garlic (Allium sativas).

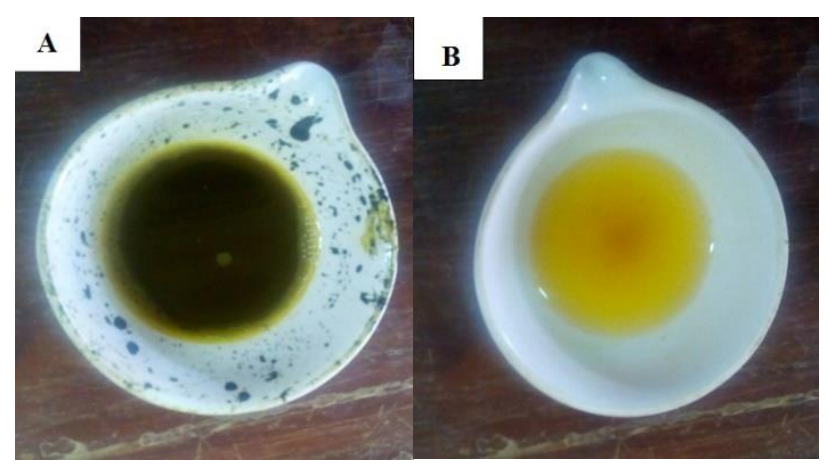

A.) Reconstituted Neem leaves extract B.) Reconstituted garlic extract

Figure 2: Reconstitutions of crude ethanolic extracts in dimethyl sulphoxide (DMSO).

\section{Antimicrobial Assay}

Neem and garlic have antimicrobial activity

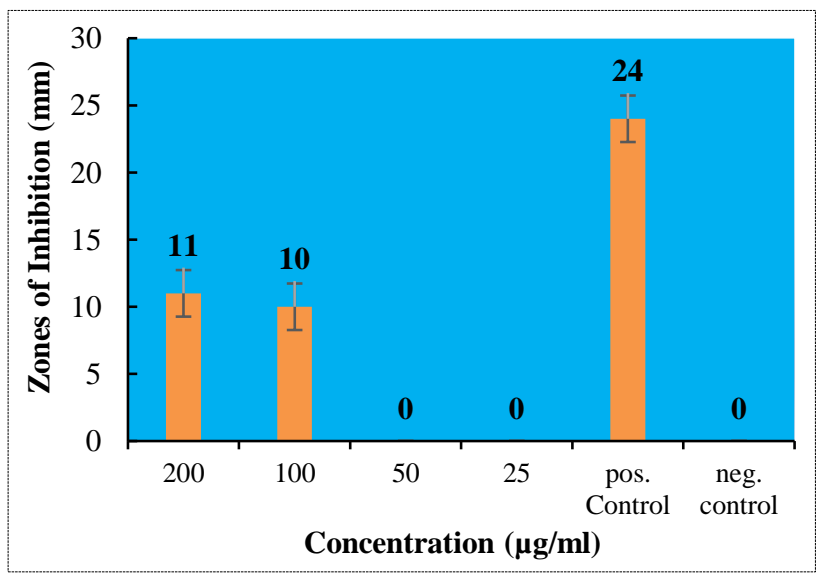

Figure 3: Average zones of inhibition of the neem extract $(\mathrm{NE})$ concentration $(\mu \mathrm{g} / \mathrm{ml})$ against $S$. aureus. 
Neem leaves extracts showed growth inhibitions only against $S$. aureus. There were no zones of inhibitions obtained for $E$. coli. Garlic extracts showed zones of inhibition against both $S$. aureus and E. coli. The Figure 3, 4 and 5 are bar graph representations of the average zones of inhibition.

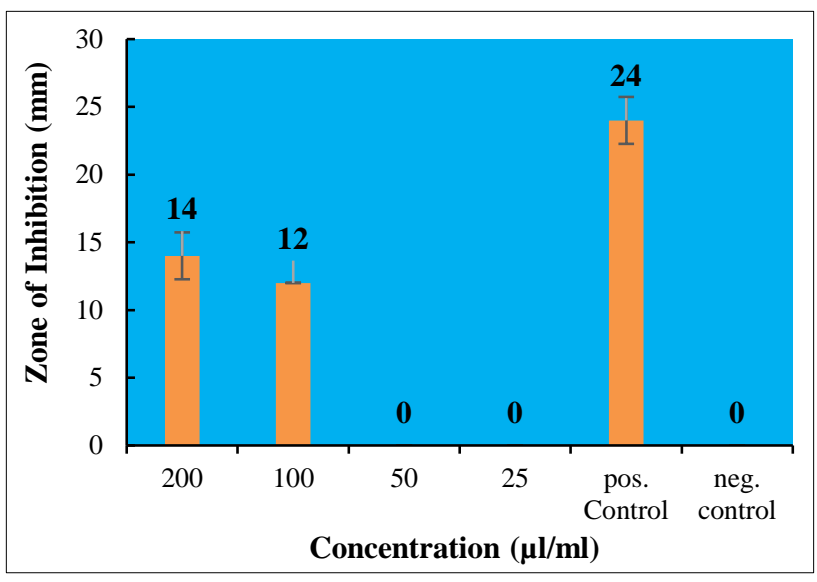

Figure 4: Average zone of inhibition of garlic extract (GE) against $S$. aureus.

Paper disk diffusion was selected as the preferred method for antibacterial activity tests and determination of MICs for the extracts because of its simplicity and cheapness. ${ }^{17}$ Both ethanolic extracts showed antimicrobial activity against $S$. aureus a gram positive bacteria, NE was more efficacious hence can be investigated further as an antimicrobial agent for bovine mastitis caused by gram positive bacteria. However, NE was ineffective against $E$. coli a gram negative bacteria. E. coli resistance to NE was also supported by other previous studies. ${ }^{13,16}$ The resistance by $E$. coli may be chromosomally mediated or plasmid mediated and changes in the intracellular environment and changes in the plasma membrane..$^{13}$ The resistance can be attributed to the antibacterial capability of NE being mainly against cell wall synthesis. ${ }^{18}$ Apart from that, the antibacterial concentration in the extract may be too low to effect any inhibition to the gram negative bacteria. GE was effective against both $S$. aureus and $E$. coli. Mechanism of action of allicin (active compound in garlic) is based on its ability to react with thiol groups of various key enzymes like alcohol dehydrogenase, RNA polymerase and thioredoxin reductase hence affecting a variety essential metabolic reaction. ${ }^{19}$ This can be the reason why GE shows much better antibacterial activity than NE. Furthermore, allicin has the ability to penetrate the lipid by layer with much ease diffusing into the internal volumes of vesicles and cytoplasm of cells. ${ }^{20}$ This showed that GE can therefore be used in treatment of $E$. coli mastitis in case of development of NE resistance. GE had high antibacterial activity against $S$. aureus meaning it is a much better antibacterial agent against gram positive bacteria than NE. In comparison to NE, GE had much higher potency. Also the growth inhibition assay for GE showed further supported its superior strength (Figure 6).

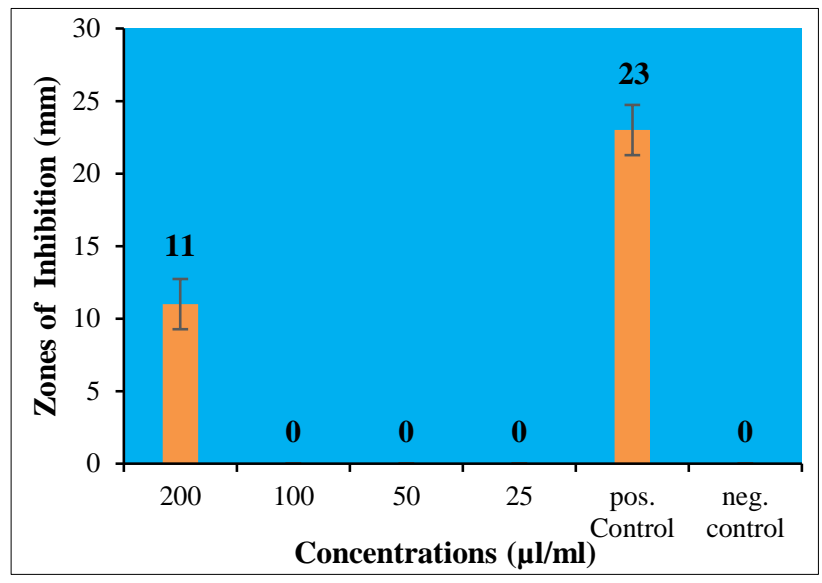

Figure 5: Average zone of inhibition of GE concentration against $E$. coli.

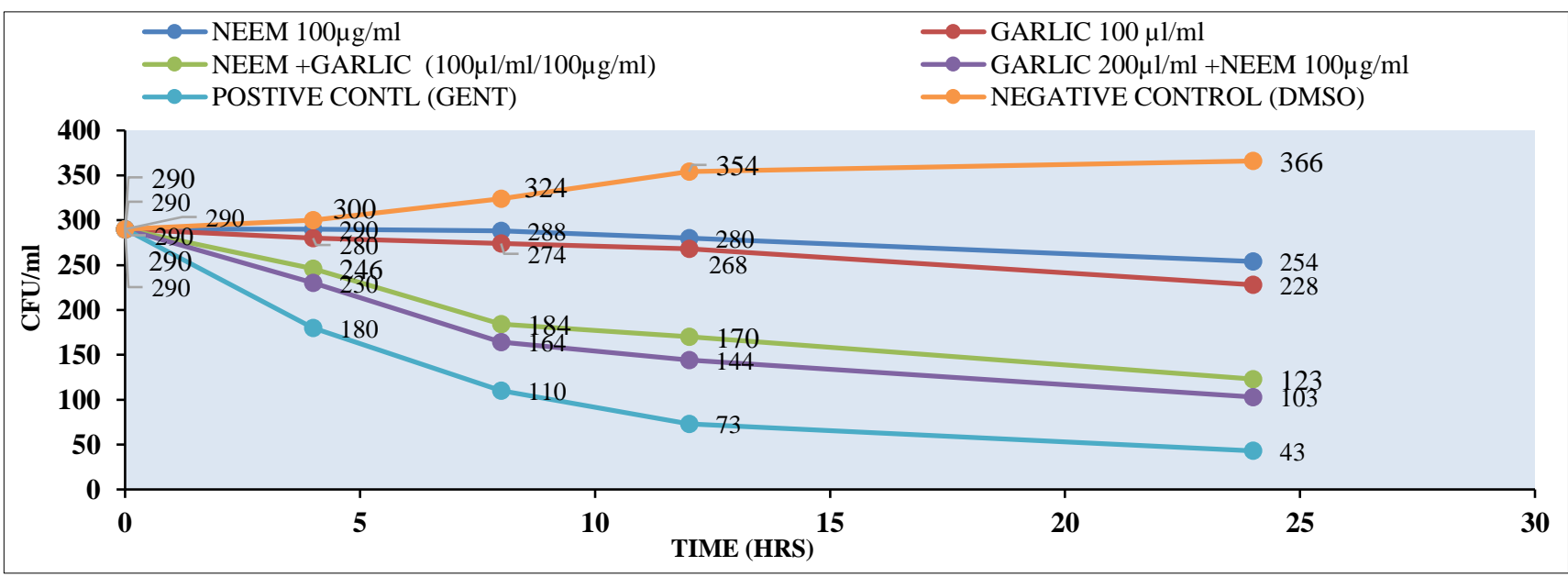

The CFU/ml values were obtained from the OD by spectrophotometry method over a period of $24 \mathrm{hrs}$ at time $0,4,8,12$ and 24 . The negative control was DMSO. Positive control was Gentamicin.

Figure 6: Synergy growth inhibition assays. 


\section{DISCUSSION}

S. aureus was susceptible to ethanolic extract at concentrations of $200 \mu \mathrm{g} / \mathrm{ml}$ and $100 \mu \mathrm{g} / \mathrm{ml}$ showing zones of inhibition of average $11 \pm 0.5774 \mathrm{~mm}$ and $10 \pm 0.5774 \mathrm{~mm}$ in diameter respectively. GE showed zone of inhibition at $200 \mu \mathrm{l} / \mathrm{ml}$ and $100 \mu \mathrm{l} / \mathrm{ml}$ with average diameters $14 \pm 0.8819 \mathrm{~mm}$ and $12 \pm 0.8819 \mathrm{~mm}$ respectively. E. coli was susceptible to GE only at highest concentration having an average diameter for zone of inhibition of $11 \pm 0.5774 \mathrm{~mm}$. This was greater than that of the highest concentration of NE further supporting the results that GE is of higher potency than NE.

In this study MIC was considered as the lowest concentration that showed zone of inhibition when the bacteria were exposed to it. MIC for NE was $100 \mu \mathrm{g} / \mathrm{ml}$ against $S$. aureus. Since $E$. coli had resistance against NE it had no MIC. MIC for GE against $S$. aureus was $100 \mu \mathrm{L} / \mathrm{ml}$. Unlike the NE, GE showed inhibition at the highest concentration against $E$. coli. It had zone of inhibition at $200 \mu 1 / \mathrm{ml}$ only hence this served as its MIC. This showed that GE was only effective at high concentration, and at this high concentration it had a higher potency than that of the NE. NE on the other hand was effective even at low concentrations despite being a weaker antimicrobial agent than garlic. This can be attributed by the fact that NE works on the bacterial cell wall hence even at low concentration it can still inhibit cell wall formation. On the other hand, GE has to be transported into the cell and once inside it has a wider number of targets hence reason for its higher efficacy.

$\mathrm{T}$ test comparisons between the positive controls and the extracts MICs showed the data was significant as all of them $\mathrm{p}$ values were less than 0.05 ( $\mathrm{P}$ values were 0.00069 and 0.00148 for GE MIC and NE MIC respectively against $S$ aureus, and 0.00985 for GE MIC against $E$. coli). In a previous study by NE against $S$. aureus showed data significance at concentrations $200 \mu \mathrm{g} / \mathrm{ml}$ and $150 \mu \mathrm{g} / \mathrm{ml}$ only, despite zones of inhibitions appearing in all the four concentrations. ${ }^{13}$

Table 1: turbidity readings for the growth inhibition assays for individual garlic MIC $(100 \mu \mathrm{l} / \mathrm{ml})$ and Neem extracts MIC $(100 \mu \mathrm{g} / \mathrm{ml})$ and there synergy against Staphylococcus aureus.

\begin{tabular}{|c|c|c|c|c|c|c|c|c|}
\hline Time & $\begin{array}{l}\mathrm{NE} \\
100 \mu \mathrm{g} / \mathrm{ml}\end{array}$ & $\begin{array}{l}\text { GE } \\
100 \mu \mathrm{l} / \mathrm{ml}\end{array}$ & $\begin{array}{l}\text { NE+GE } \\
(200 \mu \mathrm{l} / \mathrm{ml} / \\
200 \mu \mathrm{g} / \mathrm{ml})\end{array}$ & $\begin{array}{l}\text { NE+GE } \\
(100 \mu \mathrm{l} / \mathrm{ml} / \\
200 \mu \mathrm{g} / \mathrm{ml})\end{array}$ & $\begin{array}{l}\text { NE+GE } \\
(100 \mu \mathrm{l} / \mathrm{ml} / \\
100 \mu \mathrm{g} / \mathrm{ml})\end{array}$ & $\begin{array}{l}\mathrm{NE}+\mathrm{GE} \\
(200 \mu \mathrm{l} / \mathrm{ml} / \\
100 \mu \mathrm{g} / \mathrm{ml})\end{array}$ & GENT & DMSO \\
\hline & ABS & ABS & ABS & ABS & ABS & ABS & ABS & ABS \\
\hline 0 & 1.287 & 1.287 & 1.287 & 1.287 & 1.287 & 1.306 & 1.287 & 1.287 \\
\hline 4 & 1.287 & 1.298 & 1.096 & 1.086 & 1.086 & 1.076 & 1.356 & 1.156 \\
\hline 8 & 1.299 & 1.228 & 0.936 & 0.886 & 0.776 & 0.786 & 1.476 & 0.956 \\
\hline 12 & 1.258 & 1.198 & 0.626 & 0.606 & 0.706 & 0.671 & 1.616 & 0.626 \\
\hline 24 & 1.127 & 0.998 & 0.341 & 0.306 & 0.471 & 0.426 & 1.686 & 0.226 \\
\hline
\end{tabular}

+- combination of the extracts at different combinations. ABS- absorbance. NE- neem leaves ethanolic extract. GE- garlic ethanolic extract. GENT - gentamicin (positive control). DMSO - dimethyl sulfoxide (negative control).

\section{Neem leaves and garlic extracts show synergy}

The rate of bacterial growth decrease or increase was determined by measuring the turbidity of the samples and the results obtained presented on the Table 1 . Turbidity decreased (which correlated to decrease in $\mathrm{CFU}$ ) at a much high rate under GE than when exposed to NE. The Table 1 gives the turbidity results for the different extracts MICs individually and upon different combinations. Both combinations of GE MIC $(100 \mu \mathrm{l} / \mathrm{ml})$ and NE MIC $(100 \mu \mathrm{g} / \mathrm{ml})$, combination of GE MIC $(100 \mu \mathrm{l} / \mathrm{ml})$ and NE $200 \mu \mathrm{g} / \mathrm{ml}$, and combination of GE $200 \mu \mathrm{l} / \mathrm{ml}$ and NE MIC $(100 \mu \mathrm{g} / \mathrm{ml})$ had showed increased rate in turbidity decrease than when the extracts worked individually (Table 1). The results are further elaborated in Figure 6 which shows the changes in $\mathrm{CFU} / \mathrm{ml}$ of the test organism for the different extracts and their combinations. T test was used to show the difference in rate of bacterial CFU decrease between the positive control and the various combinations. If the $\mathrm{p}$ value was $\leq 0.05$ between the combinations and the positive control then the null hypothesis was rejected and synergy considered to be present. During combined therapy drugs have been shown to either have antagonism or synergism. In this study the two extracts prove to have an increased efficacy when combined in relation to the positive control hence a clear indication of their synergy. The synergistic effect may be attributed to the possibilities of the extracts affecting the bacteria at different processes in the bacteria..$^{10,16,17}$

\section{CONCLUSION}

In this study the antibacterial properties of GE and NE were tested against $S$. aureus and $E$. coli, main bacterial causative agents of bovine mastitis. Neem extract proved 
to be more effective against the gram positive bacteria but ineffective against the gram negative bacteria $E$. coli. GE was effective against both $E$. coli and $S$. aureus. In comparison GE showed higher potency than NE. This study hence showed that GE is a better antimicrobial agent than NE. Synergistic evaluation of the plant extracts showed that there was significant synergism when the two extracts were combined. This study therefore concluded that GE and NE combinations are much more effective towards treatment of bovine mastitis.

\section{ACKNOWLEDGEMENTS}

This research partially supported by Regional Veterinary Investigation Laboratory (RVIL) - Nakuru. We are grateful to our colleagues from Egerton University - Njoro who provided insight and expertise toward actualisation of this research.

We thank Mrs. Jessica, Chief bacteriologist at RVIL for assistance with synergy methodology and results interpretations, Mr. Lagat, chemistry laboratory technician at Egerton University for assistance with soxhlet extraction and Dr. V. O Adunga from Egerton University for comments that greatly improved the manuscript.

\section{Funding: No funding sources \\ Conflict of interest: None declared \\ Ethical approval: Not required}

\section{REFERENCES}

1. Ministry of Livestock Development (MLD)-Kenya. Development of a workable disease control strategy in cattle. Smallholder Dairy Commercialization Programme: 2010.

2. Somba CN. Marketing Strategies To Be Adopted By The Dairy Industry To Improve Company Competitiveness: A Case Study Of Kinangop Dairy Ltd (Doctoral dissertation, University of Nairobi): 2016.

3. Gitau GK, Bundi RM, Vanleeuwen J, Mulei CM. Mastitogenic bacteria isolated from dairy cows in Kenya and their antimicrobial sensitivity. Jour Sou Afri Vet Ass. 2014;85(1):752-7.

4. Alekish MO, Al-qudah KM, Al-saleh A. Prevalence of antimicrobial resistance among bacterial pathogens isolated from bovine mastitis in northern Jordan. Vet Med. 2013;164(6):319-26.

5. Olajuyigbe OO, Afolayan AJ. Synergistic interactions of methanolic extract of Acacia mearnsii de wild. with antibiotics against bacteria of clinical relevance. Int Jour Mol Sci. 2012;13:8915-32.

6. Thenmalar M. Molecular studies on biofilm associated Staphylococcus aureus infections in mastitis in cattle From Tamilnadu. Thesis Submitted to Periyar University. 2014. Available at: http://hdl.handle.net/10603/17446.
7. Tiwari JG, Babra C, Tiwari HK, Williams V, Wet SD, Gibson J, et al. Trends in therapeutic and prevention strategies for management of bovine mastitis: An overview. Jour of VACC. 2013;4(2):2157-7560.

8. Sivananthan M. Antibacterial activity of 50 medicinal plants used in folk medicine. Int Jour Biosci. 2013;3(4):104-21.

9. Uwimbabazi F, Uwimana J, Rutanga JP. Assessment of antibacterial activity of Neem plant (Azadirachta indica) on Staphylococcus aureus and Escherichia coli. Jour of Med Plants Stud. 2015;3(4):85-91.

10. Ncube NS, Afolayan AJ, Okoh AI. Assessment techniques of antimicrobial properties of natural compounds of plant origin: current methods and future trends. Afr Jour Biotech. 2008;7(12):1797-806.

11. Ogbuewu IP, Odoemenam VU, Obikaonu HO, Opara MN, Emenalom OO, Uchegbu MC, et al. The growing importance of neem (Azadirachta indica A. Juss) in agriculture, industry, medicine and environment: A review. Res Jour Med Plant. 2011;5(3):230-45.

12. Goncagul G, Ayaz E. Antimicrobial effect of garlic (Allium sativum) and traditional medicine. Jour Ani Vet Advs. 2010;9(1):1-4.

13. Dzulkarnain SH, Rahim IA. Antimicrobial activity of methanolic Neem extract on wound infection bacteria. Int Conf Bio Chem Enviro Sci. 2014;4(1).

14. Gafar MK, Itodo AU, Warra AA, Abdullahi L. Extraction and physicochemical determination of garlic (allium sativum L) oil. Int Jour Food Sci Nutr 2012;1(2):1-7.

15. Sadek PC. Miscibility and Solubility. In P. C. Sadek, The HPLC solvent guide. $2^{\text {nd }}$ Ed. New York, WileyInterscience; 2002:22-23.

16. Maragathavalli S, Brindha S, Kaviyarasi NS, Annadurai B, Gangwar SK. Antibacterial activity in leaf extract of Neem (Azadirachta indica Linn.) Int Jour Sci Nat. 2012;3(1):110-3.

17. Panda SK. Screening methods in the study of antimicrobial properties of medicinal plants. Int Jour Biotech Res. 2012;2(1):1-35.

18. Okemo PO, Mwatha WE, Chhabrab SC, Fabry W. The kill kinetics of Azadirachta indica a. Juss. (meliaceae) extracts on Staphylococcus aureus, Escherichia coli, Pseudomonas aeruginosa and Candida albicans. Afr Jour Sci Tech. 2001;2(2):113-8.

19. Ankri S, Mirelman, D. Antibacterial properties of allicin from garlic. Micro Inf. 1999;1(2):125-9.

20. Miron T, Rabinkov A, Mirelman D, Wilchek MQ, Weiner L. The mode of action of allicin: its ready permeability through phospholipid membranes may contribute to its biological activity. Biochimica et Biophysica Acta (BBA) - Biomem. 2000;1463(1):2030 .

Cite this article as: Edward ME, Samuel NN, Stanely W, Gerald A. Synergistic antimicrobial activity of crude ethanolic extracts of garlic and neem leaves against bovine mastitis pathogens: an in vitro assay. Int J Basic Clin Pharmacol 2017;6:21116. 